\title{
Serbian Medieval Urban Settlements
}

\author{
Stojsavljević RastislavA*, Đurđev Branislav', Đerčan Bojan ${ }^{A}$ \\ Received: May 2011 | Revised: June 2011 | Accepted: August 2011
}

\begin{abstract}
This research paper should point out general characteristics of Serbian medieval towns with special review of their formation, development and disappearance and short comparison with general characteristics of medieval towns in other parts of Europe. The fairly poor literature dealing with the study of towns in medieval Serbia has had an influence on the fact that the causes of medieval town genesis are searched for throughout Europe, thus a connection between these two occurrences is attempted to be established as well as the possibility to draw a comparison between them. This paper has attempted to find the common causes for the formation, development and disappearance of towns of a medieval type in Serbia including causes such as migrations, wars or other causes of a political and economic type. Also, the main reasons for the significant deterioration and destruction of medieval type towns have been pointed out, yet not only in Serbia, but also on the territory of the entire Southeastern Europe as well as in the countries of Western Europe and Central Europe. The previously mentioned reasons have a direct influence on the decreased possibility for the revitalization of those towns for modern, mainly touristic purposes.
\end{abstract}

Key words: Serbia, Medieval Age, settlements, Historical Geography

\section{Introduction}

The subject of medieval towns was mostly dealt with in Great Britain. C. Platt and S. Reynolds wrote about the English medieval towns as early as the I970s (Platt, I976; Reynolds, I977). If the subject matter includes the territory of Wells as well, then it is important to mention that M.W.Barley (Barley, 1975) wrote about it as well as M.Lynch, M.Spearman while G.Steel covered the topic of medieval towns in Scotland (Lynch et al., I988). One of the most prominent scientists in the field of understanding the ideology of the medieval country is R.Jones, on the example of the town under the name Gwyneed (Jones, 2002), while one of the most recent works on the towns and communes in medieval England is written by D.M.Palliser (Palliser, 2006). The pioneer of works on Serbian medieval towns in the field of historical geography is S.Novaković (Novaković, I892; Novaković, I9II) while A.Deroko continues the work in the stated field (I950). The latest research conducted on the topic of Serbian medieval towns were analysed in the work under the title 'Lexicon of towns and squares of Serbian medieval countries' written by the author Siniša Mišić (Mišić, 20Io). The congresses of historical geographers in Hamburg, Germany (2007) and Kyoto, Japan (2009) point at the increasing interest in conducting research on this subject matter (Baker, 2007; Baker 2010). When it comes to the notion of medieval town, it is important to take into consideration the fact that it differed from the notion of village not only because it was surrounded by a wall (wooden or stone) but because it had its own economy, resources and trade (Girouard, I985). The status of town on the territory of medieval Great Britain was given to towns which had cathedrals while the size of a town's population became the determining factor for receiving the satus of town as late as I888 (Beckett, 2005). In Germany, settlements which the lord freed from paying taxes were considered to be towns thus the sentence 'Stadtluft macht frei', i.e. 'City air makes you free' (Chandler, I987). In medieval Serbia, settlements surrounded by walls and with an administrative function were considered to be towns. Towns could be divided into manorial,

\footnotetext{
A Faculty of Sciences, Department of Geography, Tourism and Hotel Management, University of Novi Sad, Trg Dositeja Obradovica 3, 21000 Novi Sad, Serbia

* Corresponding author: Stojsavljević Rastislav, e-mail: rastislav.stojsavljevic@dgt.uns.ac.rs
} 
church and free royal towns. In medieval England, some of the towns were under the immediate government of the church such as Lincoln, Canterbury, Chichester, York, Bath, Hereford etc (Lilley, 2002). Some towns gained so much sovereignty that they managed to conquer the surrounding area, thus they were called town-states. The most famous examples include the following: Venice, Genoa, Veliky Novgorod, Lubeck, Hamburg, Gent, Florence, Gdansk and Dubrovnik on the territory of the Balkan peninsula. As the number of towns and their functions increased in the course of the Middle Ages, the criteria changed as well.

In medieval Serbia, in the second half of the $\mathrm{I} 4^{\text {th }}$ century and the first half of the $\mathrm{I}^{\text {th }}$ century, towns were divided into five groups (Deroko, I950):

I. Towns on the coast of Montenegro which were under the great influence of Venice and Genoa including Kotor, Skadar, Bar, Budva, Drivast, Ston etc.

2. Towns which Serbia conquered from the Byzantine Empire, starting from the conquests of King Milutin in I28I/82: Niš, Prizren, Skoplje, Velbužd etc.

3. Towns with a mainly mining function: Novo Brdo, Rudnik, Trepča, Lipnik etc.

4. Towns which represented strong forts located on strategically important points: Ras, Užice, Golubac, Maglič etc.

5. Towns which were formed in the Late Middle Ages and which are the most complex towns as regards their physiognomy and number of functions: Kruševac, Smederevo, Stalać etc.

\section{Different times of town formation in Serbia and in some parts of Europe}

A large number of towns in Great Britain was formed on the location of earlier tribal centres (oppida). Some of them became the centres of Roman districts (Wacher, 1995). The largest number of such towns can be found in the southern part of the island including the following: London, Canterbury, Silchester, St Albans, Winchester, Carmarthen, Carlisle, Cirencester, Exeter etc. Already in the $4^{\text {th }}$ century, many of them had defensive walls.

After the Romans had left Great Britain in 4IO, the formation of towns came to a standstill which lasted until the $9^{\text {th }}$ century when the Saxons, under threat from the Vikings, started building the first fortified towns. They built fortified market towns on the ruins of Roman towns as well as new towns including: Hereford, Oxford, Shrewsbury and Wilton. The Vikings also built their own towns on the location of former Roman towns including Leicester, Lin-

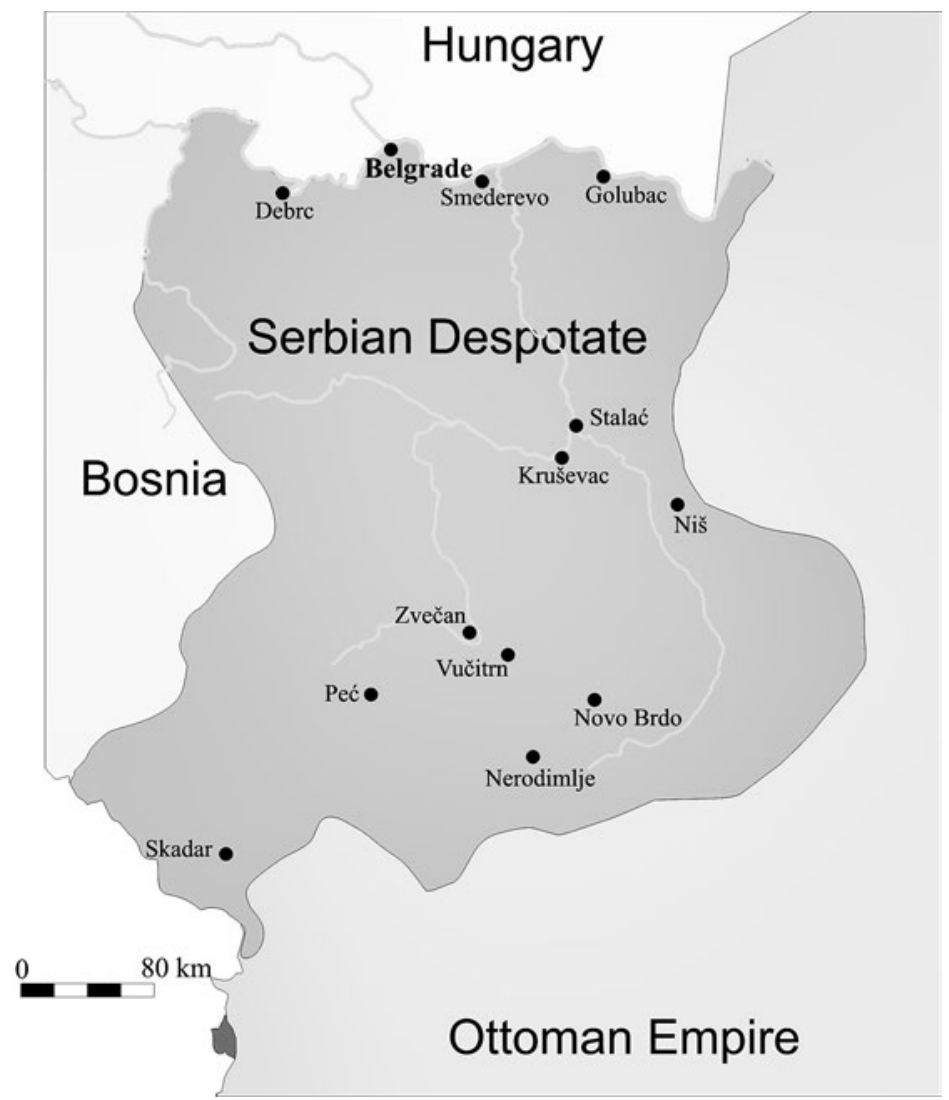

Figure 1. Serbian Despotate in the first half of the $15^{\text {th }}$ century

coln and York as well as some new ones such as Derby (Clark, Ambrosiani, I995). It is important to take into consideration the fact that from the first half of the $12^{\text {th }}$ century, almost all of these towns were fortified by wooden palisades, upon which the wooden palisades slowly started to be replaced by stone walls. Windsor can be taken as an example, a town which was fortified by stone walls during the reign of Henry Il Courtmantel (II54-II89) (South, I997). Medieval Leeds got stone walls in the year of III9.

When it comes to the neighbouring Wales, it can be said that one of the greatest builders was the English king Edward I Longshanks (I272-I307). It is also important to point out the reverse case most of the Welsh noblemen were building towns in order to protect themselves from the English invasion led by the previously mentioned English ruler. That is how the Welsh towns of Caernarfor, Conwy and Harlech were founded (Taylor, 1986).

The foundation of medieval towns in Serbia can be placed in the second half of the $12^{\text {th }}$ century during the reign of the Grand Prince Stefan Nemanja (II96-I227). In that period of time, Serbia gained its first elements of statehood. Even though the independence of the Serbian church and the establishment of the kingdom occurred several decades later, during the reign of Nemanja's son Stefan (II96-I227), Serbian medieval towns had developed slightly earlier. 
The first Serbian capital was the town of Ras in the presen day territory of Rascia. The town was surrounded by wooden walls and represents the most primitive type of medieval town in Serbia (Ercegovic-Pavlovic, I975).

Stone walls were built in Serbia from the beginning of the $13^{\text {th }}$ century with the strengthening of the Serbian economy, mining above all, when king Uroš I (I243-I276) brought German Saxon miners.

When it comes to medieval France, most towns in this area developed at the beginning of $\mathrm{I}^{\text {th }}$ century, during the reign of Philip Il Augustus (II80I223) and Louis IX the Saint (I226-I270). The medieval Aigues, which developed at that period of time, served as a starting point for the seventh (I248) and eighth (I270) Crusade (Barnaba, I993). Towns were certainly built after this period as well, especially for defence purposes, for example during the Hundred Years' War (I337-I453) between France and England.

The oldest towns in Russia date from the $9^{\text {th }}$ century. One of the most famous examples is Novgorod which was built in 862 by the Varangian chieftain Rurik (862-879) and whose development started in the $\mathrm{IO}^{\text {th }}$ century and lasted until the $15^{\text {th }}$ century (Tarabandina, 2009).

\section{The development of the urban network and the morphological characteristics of medieval towns in some parts of Europe and Serbia}

When the elements of genesis such as buildings are taken into consideration and when the ones built in Serbia are compared to the ones constructed in some parts of Europe, it can be noticed that the somewhat earlier establishment of medieval towns in Western Europe influenced their earlier development as opposed to those in Serbia. Table I presents those states from Western Europe in which building structures developed first, as well as Russia, which built towns in the medieval form early due to the migration of people, yet it was not developed enough to strengthen and develop those towns before countries such as France and England.
As it was mentioned earlier, wooden palisades were the first structures protecting medieval towns therefore their occurrence overlaps with the occurrence of a larger number of medieval towns in some countries. Thus the first palisades in England occur in the $\mathrm{I}^{\text {th }}$ century upon the fall of the Carolinian Empire when the country was divided into territories under the reign of a number of princes and lords (Creighton, Higham, 2003).

As opposed to England, France builds palisades two centuries later while Russia builds wooden palisades around towns approximately at the same time as France, when the numerous Slavic tribes joined and started a non-nomadic type of life (Morfill, I9I3).

Wooden palisades occur in Serbia at the latest, in the $12^{\text {th }}$ century, when Serbia became a politically stable country. The lack of literature addressing the period before the $\mathrm{i}^{\text {th }}$ century represents a problem, therefore it is impossible to determine whether wooden palisades existed around towns in the time of the Vlastimirović and Vojisavljević dynasties.

Stone walls represent a higher level of town development. They first occurred in England in the time of the Wessex dynasty (Glennie, I992) while they appeared in France and Russia one century later. As for Serbia, it can be noticed that towns were surrounded by stone walls only in the middle of the $3^{\text {th }}$ century, during the reign of Uroš I Nemanjić (I243-I276) when German Saxon miners were brought to Serbia. Apart fom working in mines, they were good builders as well.

Donjon towers as defence buildings appear on the territory of England from the $12^{\text {th }}$ century. The word donjon stands for dominaton point in Latin, while this term was related to the term dungeon in medieval England because war prisoners stayed in it (Beresford, Finberg, I98I).

Settlements in the vicinity of fortresses appeared in European countries at almost the same time, while in Serbia they appeared one century later. This occurrence can be related to the construction of stone walls because residential buildings in settlements in the vicinity of fortress-

Table 1. Elements of the genesis of structures in medieval Serbia and some medieval countries in Europe

\begin{tabular}{|l|c|c|c|c|}
\hline \multirow{2}{*}{} & \multicolumn{3}{|c|}{ EMERGENCE } \\
\cline { 2 - 5 } & SERBIA & ENGLAND & FRANCE & RUSSIA \\
\hline WOODEN PALISADES & $12^{\text {th }}$ century & $9^{\text {th }}$ century & $11^{\text {th }}$ century & $9^{\text {th }}$ century \\
\hline STONE WALLS & $13^{\text {th }}$ century & $11^{\text {th }}$ century & $12^{\text {th }}$ century & $12^{\text {th }}$ century \\
\hline DONJON TOWERS & $14^{\text {th }}$ century & $12^{\text {th }}$ century & $10^{\text {th }}$ century & $13^{\text {th }}$ century \\
\hline $\begin{array}{l}\text { SETTLEMENTS IN THE VICINITY } \\
\text { OF FORTRESSES }\end{array}$ & $13^{\text {th }}$ century & $12^{\text {th }}$ century & $12^{\text {th }}$ century & $12^{\text {th }}$ century \\
\hline ARTILLERY & $15^{\text {th }}$ century & $14^{\text {th }}$ century & $14^{\text {th }}$ century & $14^{\text {th }}$ century \\
\hline
\end{tabular}


es were usually built of wooden material while town walls and buldings in towns were started to be built from stone. The occurrence of dividing town walls into the Upper and Lower town can be pointed out in this case as well as the fact that they appeared at approximately the same time when settlements in the vicinity of fortresses started to develop. Settlements in the vicinity of fortresses were usually destroyed during wars as well as due to the friable material they were built of. The possibilities for their reconstruction are remote for the time being.

The peak of the medieval towns' defensive power is artillery. It appeared in the countries of Western Europe and Russia in the $14^{\text {th }}$ century while its power was especially demonstrated during the Hundred Years' War between England and France. Artillery appears in Serbia in the first half of the ${ }^{15^{\text {th }}}$ century. It was heavily present in towns such as Golubac, Smederevo and Novo Brdo.

With the ruin of the Roman Empire, urban systems started to fall apart while towns started to deteriorate. The beginning of the Middle Ages is characterised by extreme ruralisation. A number of ancient towns lost their functions which led to their stagnation and deterioration while many of them were destoyed in the rush of barbarian tribes (Bury, I958).

One of the key factors in the revival of towns are the functions mostly related to the organisation of the new Christian and feudal society. In the early Middle Ages, the European urban network was brought down to a small number of towns which succeeded to survive owing to traditional commercial connections or because they became episcopal centres (Ćurčić, I992). The only powerful and universal organisation in Western Europe at that time was the Church. The key to the new urban development cannot be found if the role of monasteries is not taken into consideration. Namely, the closest connection between classical and medieval towns was not in the surviving buildings and customs, but in the monasteries (Aurell, Power, 2006). The monastery was the new type of town with its own economic base. Monasteries were primarily built in rural areas, while in the course of urbanisation, they became integral parts of urban structures with a high importance and on specific locations (Herlihy, 1970). Examples of medieval towns whose bases of development were religious institutions include St.Gallen, Limoges, Baune and many others. Beside monasteries, an important basis of development of a number of towns was either a fortress or a burg. From the $9^{\text {th }}$ to the $13^{\text {th }}$ century, many castles were built in Europe which became the basis of development of many towns (Bremen, Innsbruck, Munster) (Creighton, Higham, 2003). In France, in the first phase of development, a large number of towns - chateau - was built (Chateauroux, Chatellerault, Chateaudun). In the $13^{\text {th }}$ century, fortified towns known under the term bastide were built mostly in the southwest of Europe ( Saint Andre, Sarrant, Sabonneres) (Mesqui, I997; Gebelin, 1964).

Economical and political changes led to the reconstruction of many old towns and the building of new towns. New towns are especially numerous in the peripheral parts of Europe in which the urban civilisation did not have a tradition, such as Germany, Poland and Russia and on the main paths of the European colonisation. A number of new towns were boundary watchtowers such as in Gascony, Wales and Pomerania. However, that process was slow, so the European network of towns reached Poland in the $13^{\text {th }}$ century, Scandinavia in the $14^{\text {th }}$ and $15^{\text {th }}$ century and Panonian Podunavlje only upon the suppression of the Turks, i.e. in the $18^{\text {th }}$ century (Ćurčić, I992).

On the basis of the town network from the year of 800 , it can be said that Byzantium and Spain had the most developed settlement systems (Vresk, 2002).

In Byzantium's urban system, Constantinople stood out as the biggest town until the year of I300 (Herrin, 2008). In 800, it had 300,000 citizens. Besides Constantinople, the towns of Thessaloniki, Corinth, Syracuse, Athens, Sofia, Plovdiv stood out in the Byzantine Empire, yet, when it comes to size, they were much smaller than Constantinople (Harris, 2007; Treadgold, 1997).

In the $8^{\text {th }}$ century, the largest part of Spain constituted a component of the great Arabic country. That was an Islamic cultural circle in which towns were centers of social life. Therefore it is understandable that in that part of Spain a large number of towns, which stood out for their size in the Middle Ages, developed (Chartrand, 2006). Cordoba had 160,000 citizens in the $8^{\text {th }}$ century. The Cordobian Caliphate had a thick network of towns including: Seville, Merida, Toledo, Barcelona, Valencia, Almeria, Saragossa, Murcia, all of which had from 15,000 to 40,000 citizens (Tejada, 1999).

Besides Rome, which had 50,000 citizens in the $8^{\text {th }}$ century, the towns of Naples, Benevento, Amalfi and Bari stood out in Central and Southern Italy. Until the end of the Middle Ages, the town network in Italy had been constantly expanding so that in the $\mathrm{IO}^{\text {th }}$ century the towns of Genoa, Bologna and Pisa emerged. In approximately I300, the largest Italian town was Venice with approximately IIo, ooo citizens followed by Milan and Genoa with Ioo,ooo citizens (Vresk, 2002).

Present day France was also singled out by the thickness of its town network in the Middle Ages. 
A number of Roman towns in France maintained the development continuity in the Middle Ages mostly due to the functions many towns took over with the introduction of Christianity. One of the first towns to become an episcopal town was Lyon, while in around 200 other towns emerge in the south including: Arles, Narbonne, Toulouse, Limoges, Clermont-Ferrand, Bourges and Tours (Gebelin, I964).

The urban network of Germany spread gradually with the Germans' expansion towards the East. Cologne was the largest and the most important town all through the Middle Ages. In the time of Carolings, important centres developed on the eastern borders including: Hamburg, Magdeburg, Halle and Erfurt. In Southern Germany, significant centres included Regensburg, Augsburg, Ulm, Nuremberg while in the zone of the Alps, on the territory of present day Switzerland, significant centres were Basel, Zurich, Konstanz and others (Buse, 2005).

On the territory of the Netherlands, the urban network developed later than in Flanders and other Belgian provinces because there were no Roman towns which would have served as the bases of new urban development. The first towns on that territory appeared in the $12^{\text {th }}$ century including Utrecht, Nijmegen, Groningena and Leiden.

In Great Britain, until the invasion of the Danes in the $9^{\text {th }}$ century, there had not been a significant development of towns. Only then and especially during the reign of Alfred the Great, numerous fortifications were developed since a plan for the defence of the country was made (Pounds, 1994). Walls of Roman towns were used for the construction of some fortified towns which played a highly important role in the battle against the conqueror including Hastings, London, York and Chester (Cathcart, David, I988).

The development of the urban network in Poland started with the erection of the Gniezno and Poznan castles and together with them the first Polish towns developed including Warsaw, Lublin, Plock, Krakow and Wroclaw.

The first medieval towns were small. Paris was located on the small island of Cite for a long time, entire Bologna was placed inside an old Roman castrum while Split was placed in the palace of Diocletian. The towns which managed to be fortified against the attacks of the Barbarians occupied a significantly smaller area compared to the one on which they had previously expanded. Bordeaux was reduced to the third of its previous size by being fortified with new walls while Autun, a town founded by Augustus, was reduced to a Ioacre settlement from a once 200-acre town. In Nimes, the Visigoths turned the old amphitheatre into a small town with two thousand citizens and two churches. When they closed the arena entrances, its thick outer walls served as bulwarks. The walls of Arles built by Theodoric were destroyed again in the battle between Karl Martel and the Arabs. Afterwards, the amphitheatre in Arles served as a fortress in which a small medieval town emerged, a town overcrowded more than usual (Mumford, 200I).

The spatial structure of medieval towns was complicated. Many towns developed gradually, in the course of several centuries, therefore there existed periods of slower and faster development in the conditions of different social circumstances and technological possibilities. Thus more or less clearly expressed genetical, i.e. morphological and functional elements can be noticed in the spatial structure of many medieval towns including a castle, the centre of secular government, then the complex of religious institutions (church, cathedral, monastery), the complex of town government with a town hall, the complex of facilities related to the town's economic life (market, trade guild buildings, manufacturing workshops), residential areas (Coulson, 2003).

A castle represented the centre of development of many medieval towns. There were royal, earl, duke, knight castles as well as monasterial castles while cathedrals sometimes had their own castles as well. Compared to the rest of the town, the position of the castle was different, depending on the terrain configuration, defence possibility and time of building (Creighton, 2002). In some towns, the castle is in the centre of the town, primarily in those which developed on the ruins of Roman towns (Konstanz, Passau, Utrecht etc.). In other towns, the position of the castle is marginal while in some towns the castle is separated from the town and it is located in a specially chosen place (Bamberg, Eger, Brandenburg, Hannover etc.). Many castles were built in specific locations which enabled the construction of a good defensive system (towering cliffs, hills, islands) while the manufacturing and trading settlement developed as a settlement in the vicinity of a fortress beside water or land routes.

In towns, there were monasteries with their own churches. Monasteries in towns constituted separate complexes, often with a defensive wall (Erlande-Brandenburg, I995). Those were monasterial castles .The castle and the cathedral were the most important elements in the spatial structure of the town (Morris, 2004). They symbolise the church and feudal lords as the main bearers of political and spiritual power of the medieval society.

The most developed form of town was civitas. That status was primarily given to episcopal, royal and monasterial towns while other towns 
gained that status later whether by means of royal charter or by usurpation. Locus, oppidum or burgum differed from civitas due to the fact that they lacked civitas's freedom (Vresk, 2002).

For the needs of town government town council and mayor, town houses and town halls were built in towns. In some towns, they were built in the $12^{\text {th }}$ century while in the $13^{\text {th }}$ century they existed in all of the free towns.

The town square was multipurpose and it took a specific position in the town. It served for the exchange of goods, therefore as a town market, then for public gatherings, religious ceremonies, army parades, various kinds of festive events etc (Johnson, 2002). In the course of development, different forms of town squares emerged. The form largely depended on whether the town developed according to a plan or spontaneously.

In towns which developed on the remainings of Roman towns, the squares kept a regular shape while in those which developed spontaneously, the squares mostly had an irregular shape. In towns which developed according to a plan and regular rectangular schemes, one block in the central part was left for the town square and due to that the squares had a regular shape.

The plans of medieval towns, the layout of streets, land parcels and buildings also have their specific characteristics. Towns which remained from the Roman days (Cologne) usually kept their tetragonal parcelation system and block construction in the very centre, yet they were partially modified by the construction of citadels and monasteries as can be seen in Table I. The spontaneous development conditioned the development of irregular structures. Towns which slowly emerged from villages or groups of villages around a monastery or castle were better adjusted to the topography, slowly changing from generation to generation, often keeping in their plans the characteristic features which were more a result of historical coincidence than conscious choice. In towns which developed spontaneously, a concentric shape is often noticed because the town developed around one building: a castle, monastery, cathedral, town square or market.

When it comes to the spatial structure of medieval towns, one of their most important characteristics is their defensive system. At the beginning, fortifications included embankments, ditches filled with water and wooden palisades. When being built, natural advantages were often used including slopes, water surfaces, cliffs. The town wall was the most significant element of the town's defensive system as well as the symbol of the medieval town. Towers and wooden balconies were placed on the walls. There were usually between 20 and 40 towers. The town gate was built in the walls and it was well kept and locked. The number of town gates was also different, while some towns had only one gate (Kenyon, I99I). One of the best examples of medieval fortification architecture is the town of Carcassonne in France.

In fear of invasion, the inhabitants of Mainz, for example, rebuilt their ruined Roman walls. As ordered by Heinrich $\mathrm{I}$, walls were even built around monasteries in order to be protected from the attacks of pagans. The monastery of Saint Omer was destroyed twice by the Vikings in the $9^{\text {th }}$ century (in 860 and 878). However, when the Vikings returned in the year of 89I, they saw that the abbey had erected a wall and that it could successfully confront them. This renewed way of achieving security was so successful that aready in the $\mathrm{IO}^{\text {th }}$ century the monastery of Saint Omer became a real town.

In the year of 913, it was recorded that the construction of fortifications and walls around settlements was one of the chief activities of the royal army. Yet, already in the year of 885 , the very inhabitants of Rochester fortified their town with a wall and defended it successfully while a year later King Alfred himself fortified London. Military service became a town necessity and it is even possible that the ability to maintain a standing army and repair the wall around the town was one of the qualifications for getting the status of an urban place. Although the right to constructing a wall remained a royal prerogative, that right was given to free towns in Italy as well by means of the Peace of Constanz in II84.

Extending the wall from a castle or abbey to a nearby village usually denoted the physical start of town development although all the legal privileges of an active town body could be gained only by means of tough negotiations with the bishop or feudal lord who owned the land. The greatest economic privilege - the right to hold a fair regularly, once a week, which gathered the local farmers, fishermen and craftsmen - depended on the physical security and legal consistency of the town (Gies, Gies, 1974). The fact that traders represented a new class can be concluded from their settlement in the newly built suburbs in front of the town walls. At the beginning, the town centre was in the castle or monastery and after the $\mathrm{II}^{\text {th }}$ century $\mathrm{AD}$ the activities of the social community started to move towards the market, while the acceptance of traders and craftsmen as free citizens was in many places shown by extending walls around their suburbs. Such an example is Regensburg which, besides a royal and church district, also included a traders' district in the $\mathrm{II}^{\mathrm{th}}$ century.

When it comes to the morphology of Serbian medieval towns, significant differences can be noticed between towns which were built at the end 
Table 2. The shape of the basis and structure of chosen medieval towns

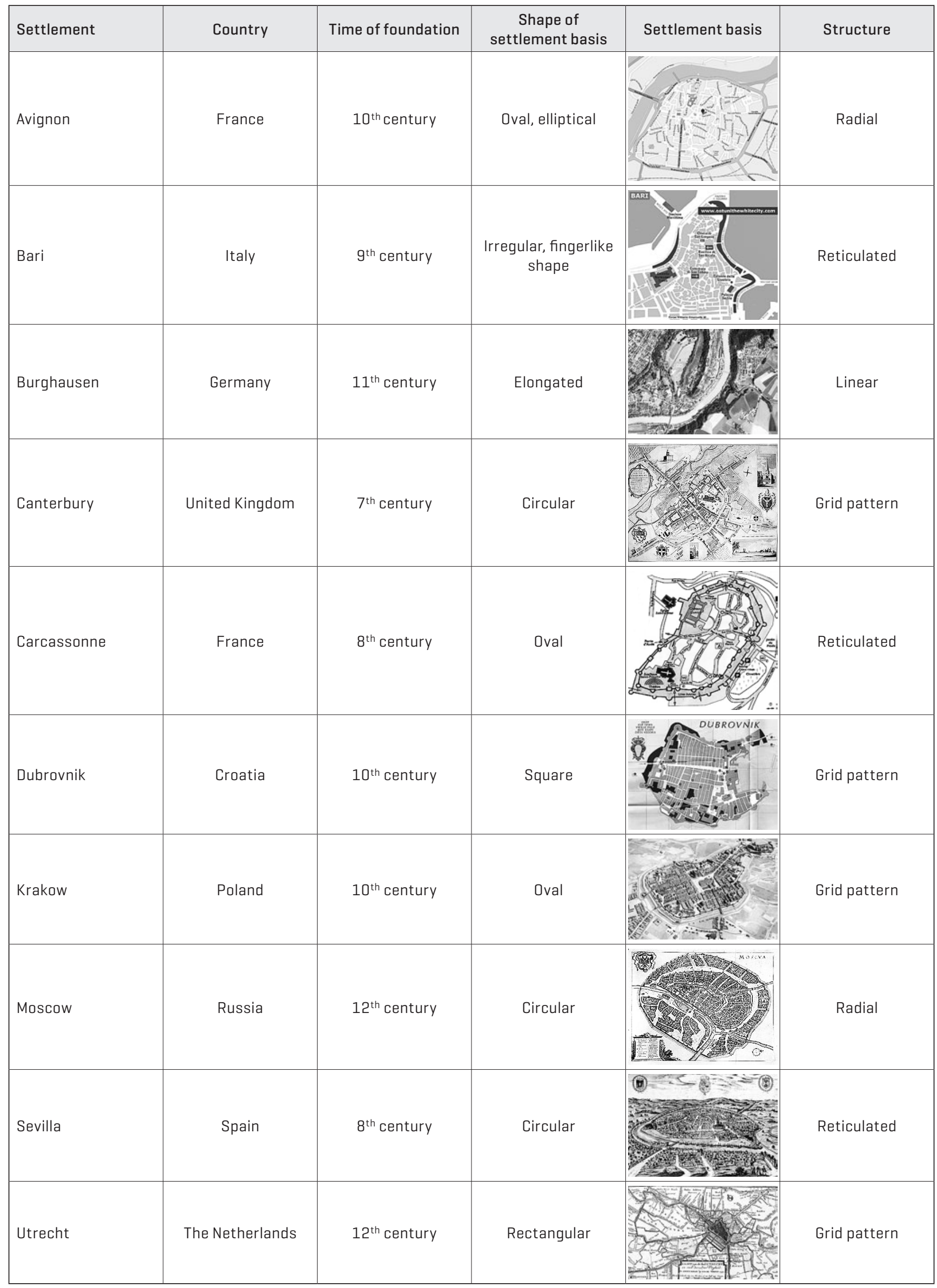


of the $12^{\text {th }}$ century (Ras) and towns which were built two or three centuries later (Novo Brdo and Smederevo). If the morphological structure of medieval Ras is taken into consideration, it can be noticed that the town consisted of only one part as opposed to towns emerging later, ones which had settlements in the vicinity of fortresses. The fort had an irregularly elongated base which was I8om long in the direction north-south and 20$60 \mathrm{~m}$ wide in the direction west-east, while the entire fort was surrounded by stone bulwarks and the more accessible sides of the fort were defended by means of two towers between which the western gate was placed (Ercegovic - Pavlovic, I975). The bulwarks were between I.6om and 2.I0m thick while their height was greater on the accessible sides of the town and lower towards the cliffs. Still, it did not exceed 7m (Kovacevic, I977).

In front of the main town bulwarks, one more outer defensive line can be noticed (Figurer).

From the nort, west and south side, approximately $50 \mathrm{~m}$ in front of the stone town bulwarks, there was an earth bulwark with a wooden palisade. The medieval town of Ras had a fairly simple morphological structure which was suitable for the beginnings of town building in these areas.

Unlike medieval Ras, the medieval fort of Novo Brdo, which was built at the beginning of the $\mathrm{I}^{\text {th }}$ century, contained a settlement in the vicinity of a fortress. The settlement of Novo Brdo stretched east and southeast from the town. The fortress contained the Upper and Lower Town (Gornji and Donji Grad). The Upper town was of a hexagonal shape (Boskovic, I972). The Lower town, which had a fan-shaped base, stretched in the direction of west below the Upper town. The length of the Upper town in the direction north - south was 5om while the width in the direction of west - east was $45 \mathrm{~m}$. The Lower town was I8om long in the direction north - south while its width in the direction of west - east was $95 \mathrm{~m}$ together with the Upper town. There was a trench around the walls and the walls could be approached only from the eastern side. The civil settlement or settlement in the vicinity of a fortress was placed east from the Upper town and it was constituted from stone houses lined up along the narrow paved streets. The town was not built from bricks, but from stone only. Since the town lies on reserves of Pleozoic limestone, it was mainly built from this rock material (Zdravkovic, I958). Sand and gravel mortar was used as connective material. Since the town is well-preserved, three construction phases can be recognised: in the first the Upper town was built, in the second the Lower town was built while the third phase followed one century later when the town was being rebuilt after the Turkish attacks.

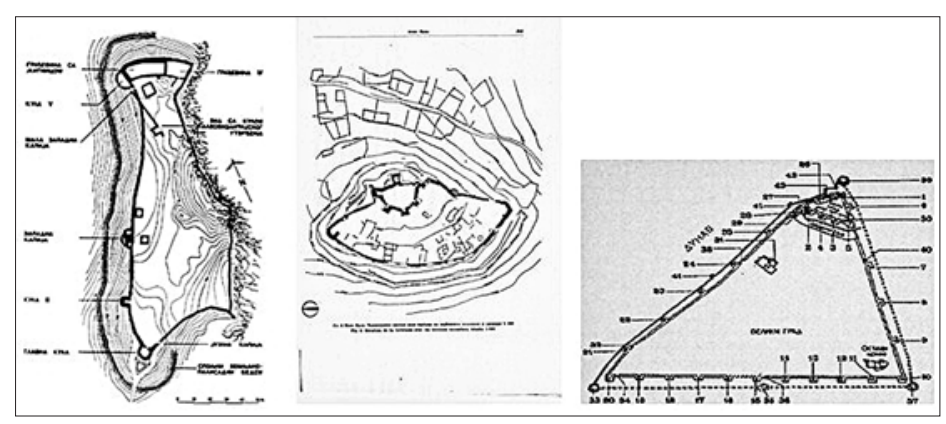

Figure 2. Shape of the basis of medieval towns: Ras, Novo Brdo and Smederevo

As it can be noticed, the medival fort of Novo Brdo is much more complex in its form than medieval Ras. A more complex morphological structure can be found in the largest Serbian medieval town Smederevo as well, which was built in the third decade of the $15^{\text {th }}$ century. The fortress of Smederevo has a triangular shape. The town is surrounded by water on two sides while the third side is faced towards land. There was a wide trench on the land side serving as the first line of defence. The fortress of Smederevo was constituted from the Big and the Small Town. The entire town was built of stones of various composure. Due to the rapid construction process, there had been a lack of construction material so it was taken from some Roman and Ancient monuments such as Mons and Viminacium (Petronijevic, 2006). The length of the triangle sides of the fortress of Smederevo were uneven. The length of the side facing the Danube was $550 \mathrm{~m}$, the side facing River Jezava $440 \mathrm{~m}$ while the side facing land was $502 \mathrm{~m}$ long. The walls were approximately Iom high while their width was around $4.5 \mathrm{~m}$. The town had 25 towers. Some towers were over $20 \mathrm{~m}$ high and over IIm wide while the entrance gate contained a bridge over the trench surrounding the town from the land side (Novakovic, I982). Five construction phases can be recognised on the fortress of Smederevo in the period of 60 years.

From the analysis of the three medieval towns built at the beginning, at the peak and at the end of the Serbian country's economic power, an evolution in the morphological structure is noticed with the rise of the economic and military power of the country. Additionally, in the period after the Battle of Maritsa in I37I and the Battle of Kosovo in 1389 , when the threat of Turkish conquests emerged, forts were built with many more defensive characteristics than in earlier times.

The beginning of the Middle Ages welcomed the settlement and gradual grouping of Slavs on the Balkan peninsula, yet the first elements of statehood appeared as late as the $12^{\text {th }}$ century when the first simple fortresses were built, unlike in other European countries where towns were 
under full development at that time. Unlike some medieval towns from some European countries, residential buildings inside the fortress were built from wood which was the cause of their frequent collapse. The consequence of the previously mentioned is that there are no remainings of settlements around any of the medieval fortresses on the territory medieval Serbia had occupied.

\section{Number of medieval castles in some medieval countries}

The true reflection of the development of towns in a medieval country is certainly represented by their number and the distance between them which was important for a successful trading cooperation. Table 2 represents the number of towns in significant European countries in the Middle Ages.

Table 3. Number of towns in some european countries

\begin{tabular}{|l|r|}
\hline Country name & Number of towns \\
\hline Germany & 3659 \\
\hline Hungary & 1322 \\
\hline France & 874 \\
\hline England & 615 \\
\hline Scotland & 575 \\
\hline Ireland & 342 \\
\hline Italy & 332 \\
\hline Serbia & 320 \\
\hline Poland & 228 \\
\hline Spain & 164 \\
\hline Wales & 162 \\
\hline Russia & 79 \\
\hline Northern Ireland & 67 \\
\hline
\end{tabular}

(Dickinson, 1945; Meurer, 1914; Pirenne, 1948; Tout, 1934; Clarke, 1926; Clive, 1936; Laszlovsky et al., 2003; Koter, Kulesza, 1999].

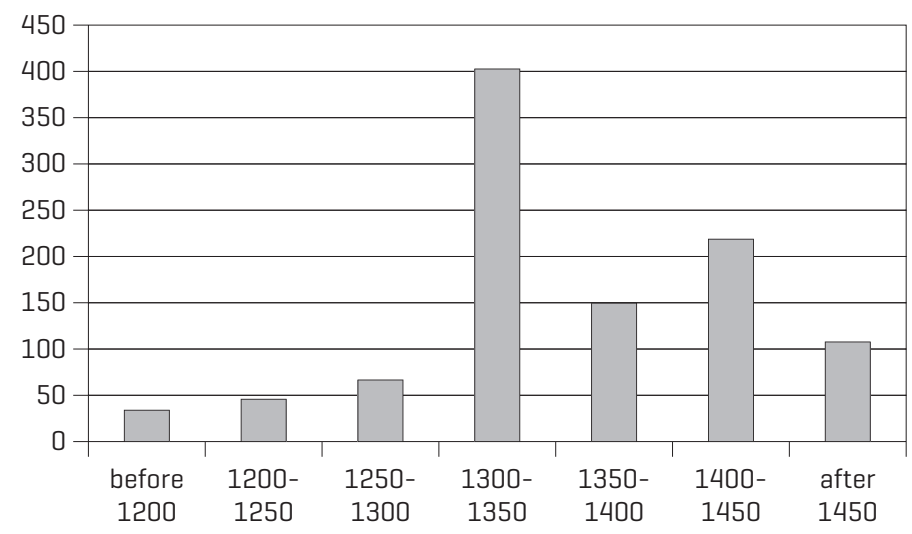

Figure 3. Number of towns in medieval Serbia by time period Source: Stojsavljević, Djurdjev, Djerčan [2010]: Serbian medieval towns and their tourist potentials, Geographica timisiensis, Vol 19., No. 1, West University of Temisoara, pages 189 - 196
As it can be noticed, Germany is first in the number of towns owing to the size of the territory it occupied and it is immediately followed by Hungary. If we added together the number of towns which are today located on the territory of Great Britain, we would get the number I4I9 and that would take up the second place in the table.

The medieval Serbian country comprised the territory of present day Serbia, Macedonia, northern Albania, Montenegro and western Bosnia and Herzegovina (Cvijic, I922). A total of 320 medieval towns having emerged at different periods of time has been found in this territory.

When analysing Chart I, it can be noticed that the smallest number of towns of medieval Serbia existed at the beginning of the period in question, i.e. before the year I200, when there were 35 towns. That was the time of the emergence and formation of the Serbian country which had reached its true form during the reign of Stefan Nemanja. After the death of Desa of Serbia who was constantly pressurised by the Hungarians, Bulgarians and Byzanthinians, a civil war among his grandchildren broke out from which Stefan Nemanja emerged as the winner. By conquering Zeta in II80, there had been a significant expansion of the country which increased the number of towns within the Serbian country. The reasons for such a small number of towns were the still undeveloped economy and trade as well as the population still in the process of settling in the newly formed Serbian regions. Towns in this period were mostly inherited Byzanthinian towns or towns with ancient foundations, while a significant number of towns was located in the littoral area of Zeta, Zahumlje and Travunija. The most famous include Bar, Budva, Ras (Grand Prince Stefan Nemanja's capital), Gradac, Kotor, Niš, Prizren and others.

When it comes to the period from I200 to I250, it can be established that there were 47 towns on the territory of the Serbian countries, which means that the number was increased by I2. The reason of the previously mentioned were not important conquests beacuse the territory was basically the same, but the strengthening of economy and certainly the rise of the Serbian country to the rank of kingdom in the year of I2I7. Besides the existing towns from the previous period, the towns of Brskovo, Livno and Skoplje emerged here.

In the following period from 1250 to 1300 , the number of towns was increased to 68 . The rapid development of economy had definitely contributed to that. Mining centres managed by the German Saxon miners brought to Serbia by king Stefan Uroš I (I243-I276) started to be opened. That contributed to a larger number of towns on Kosovo and Metohija as well as to the building of 
towns on the crossroads which gained a higher importance by the development of trade.

Also, the conquests started by King Milutin in I282/83 influenced a large number of towns located in present day southern Macedonia to become part of the Serbian country until falling under the Turkish reign at the end of the $14^{\text {th }}$ century. The newly built towns in this period of time included the following: Braničevo, Velbužd, Debrc, Jeleč, Kičevo, Peć and others.

A significantly larger number of towns appeared in the first half of the $14^{\text {th }}$ century, i.e. in the period spanning from 1300 to 1350 , when there were I03 urban settlements in Serbia. The conquests of King Dušan (Tsar as of I346), who conquered several towns in southern Zeta and southern Macedonia, had certainly contributed to this. Numerous towns conquered in present day Albania and Greece cannot be taken into consideration beacause, as stated earlier, they remained under Serbian reign for a too short period of time and they belonged to the Byzanthinian buliding style as per their physiognomy. The reason of the increase of the number of towns by 35 should be searched for in the fact that during the reign of Dušan Serbia was the leading economic and military force on the Balkans. The consequence of that was the development of trading especially with Dubrovnik and the Republic of Venice which enhanced the development of caravan traffic and crafts. In this period of time, the Bosnian country ruled by Ban Stjepan Il Kotromanić was extremely powerful thus the building and development of towns there was accelerated as well. The most famous towns emerging in this period of time were: Novo Brdo, Srebrnik, Prosek, Temac, Leskovac, Janjevo and others.

In the following period spanning from I350 to I40o, the trend of increase in the number of urban settlements continued and there were I5I of them at that period of time. The benefits of Dušan's reign influenced the sense of prosperity to be felt even after his death despite the friction between Serbian magnates and the increasing separation between the regions. Namely, in the course of the $\mathrm{I} 4^{\text {th }}$ century, not only new urban settlements were built, but rural settlements grew into urban settlements as well. As the Serbian territory often changed, some rural settlements, by reaching the intersection of commercial roads, became trading centres or squares which served for the exchange of goods.

The second explanation supporting the further increase of the number of towns are the Serbian defeats in the Battle of Maritsa in I37I and in the Battle of Kosovo in 1389 when the threat from the Turks emerged, especially in southern Serbian countries. That is the reason why a large num- ber of towns with an exclusively defensive function was built due to the overwhelming number of Turkish soldiers in the battles with the Serbian army as well as other Christian armies. The most famous towns from this period are Kruševac (Lazar's town), Prilep, Stalać, Koprijan, Vučitrn and others.

The culmination of the number of medieval urban settlements in Serbian countries was reached in the period from I400 to I459. There are two contradictions in this period of time which might have had a crucial influence on the number of towns counting 220 towns, i.e. 69 towns more than the previously analysed period of time. The first is that the Serbian economy was still strong. For the sake of providing an example, it is important to point out that Novo Brdo brought up to 200,000 ducats per annum to the Serbian Despot Đurađ Branković.The second is that under the threat from Turks, walls were built around numerous villages which were distant from some towns, thus they were separately defended. The Serbian capital of Smederevo was built in the period from I428 to I430 because Belgrade, after the death of Despot Stefan Lazarević, fell under the rule of Hungary.

The first fall of Serbia under the reign of the Turks in the period from I439 to I444 influenced the destruction of a large number of towns, yet most of them were rebuilt after this period only to be finally destroyed first in 1456 and then in 1469 . A large number of towns in this period was located in Bosnia of that time ruled by Stjepan Vukčić Kosač who listed all the towns in his territory on two occasions, in the census of I446 and I454, which represent the most valuable commemoration of the towns of Bosnia in the $15^{\text {th }}$ century taken into consideration in this work. The towns of this period include: Smederevo, Visoki, Žabljak, Koznik, Ostrovica, Ravan, Hum and others.

The last analysed period is related to the time after I459, when medieval Serbia fell under the reign of the Turks. An important year for this section is the year of $\mathrm{I} 463$ when medieval Bosnia fell under the reign of the Turks as well as the year of I468/69 when the first Turkish Defter (cadastral tax census) of the newly conquered areas was conducted. The fact that the number of urban settlements was reduced for more than twice is important because the number of towns surviving the Turkish conquests was only Io 8 which is II2 less compared to the previous period.

\section{The detorioration of medieval towns}

In most European countries, medieval towns have been restructured and serve for tourist purposes. Examples of well-established medieval cul- 
tural heritage are numerous throughout Europe. Successfully valorized spatial, cultural and historical wholes exist in England (Windsor, Lincoln Castle, Dover Castle etc.), then in Scotland (Bothwell Castle, Caerlaverock Castle, Edinburgh Castle), Ireland (Blarney Castle, Dublin Castle), Wales (Caerphilly, Conwy), France (Avignon, Foix, Moint-Saint-Michel etc), Spain (Alcazar, Castillo de Coca etc.), Italy (Bari, San Gimigniano, Fenis, Sacra di San Michele etc.), Germany (Neuschwanstein etc.) and Eastern Europe (Ciechanow-Poland, Karlstein-Czech Republic, Bran-Romania) (http://www.medieval-castles.net/castles.htm).

One of the main reasons of abandoning medieval towns in Europe is definitely the growth of population and their expansion. One of the reasons was also the change of economic and social relations from feudalism into capitalism. The town population was developing more and more and becoming equal with the gentry. As far as the Serbian medieval towns are concerned, this occurrence was not so frequent because the Ottoman Empire, regardless of its power and the peak it reached in the middle of the I6th century, was present with the backwards feudal system and the Sharia law (Kunt, 2003). While the countries of Western Europe embarked on large geographical discoveries and brought treasures from newly discovered countries, the Ottoman Empire was still in the feudal social system, so the towns on its territory had still kept the medieval look and character, while such towns had already disappeared or changed in the countries of Western Europe.

The reason of the disappearance of the look of medieval towns was also the invention and development of the use of firearms whose power medieval fortresses could not resist thus other ways of constructions were approached. It is considered that towns which were built in the Middle Ages ceased to be built in Western Europe from the end of the $15^{\text {th }}$ century.

Still, there were cases of developing townstates in the late Middle Ages on the territory of present day Italy. As stated by D. Vigneswaran (Vigneswaran, 2007), on the territory of present day Toscany and Lombardy, from the $12^{\text {th }}$ century to the $16^{\text {th }}$ century, town-states emerged as variations in Europian territoriality. In Germany, also in this period of time, towns which had the status of free towns strengthened, only to expand their network after the year of I648 (Ribhegge, 2003).

When Serbia is in question, it is believed that towns did not disappear due to economic reasons but due to being conquered by the Turks who changed them and did not do anything on their improvement and harmonisation with the new times. When medieval Serbia fell under the reign of the Turks in I459, most towns in Serbia were either damaged or destroyed. The same situation occurred in medieval Bosnia after the year of 1463 . The Turks did little reconstruction on the towns, especially on those in the provinces because there was no need to protect towns when there was no one to attack them. A large part of the population of Serbia and Bosnia migrated northwards, across the Sava and Danube, at that period of time. The Turks fortified only those towns which were located in the vicinity of the Sava and Danube in fear of attacks from Hungary (Golubac).

Upon conquering these territories, the Turks embarked on constructing their own settlements, barracks and mosques taking most of the material from medieval towns which remained abandoned and useless due to the previously mentioned. The towns which were not destroyed by the Turks and which were used as fortresses, were built in a different manner. Namely, due to the ever increasing power of firearms, especially after the $15^{\text {th }}$ century, low towers were being built, sometimes even in the level of ground floor so that they would not be an easy target for the attackers (Šabac).

The construction material from medieval towns was also taken by the Serbian local population for the construction of their houses which were now built from stronger material. The Turkish authorities did not care much about the deterioration of Serbian medieval towns.

The deterioration of Serbian medieval towns was also influenced by the depopulation in the areas surrounding towns because of the fall of the economic power of the towns due to the extinction of villages in their surroundings. According the Turkish censuses from 1456, there were even 74 abandoned Serbian villages in the surroundings of Novo Brdo, villages people escaped from due to the danger from the Turks. It is considered that the whole area surrounding Novo Brdo lost around 30 thousand inhabitants in the period from 1385 to I455 (Macura, 200I). The deterioration of medieval towns in Serbia on the example of Novo Brdo is supported by the fact that this fortress had around 9000 inhabitants at the peak of its mining power only to lose around $3 / 4$ of population after its subsequent fall (Rasevic, I996).

\section{Conclusion}

When comparing the time of formation of Serbian towns and towns in some parts of Europe, a difference of two whole centuries is noticed between Serbia and Great Britain. The same relation is noticed with Russia as well, while in medieval Serbia and France, towns started developing at approximately the same time. The main cause was certainly the end of the great migrations of people at the time when the European economy and trade 
started to develop, which accelerated the need for the rapid growth of the number of towns.

The second cause is the emergence of statehood elements which were noticeable in England during the reign of the Wessex rulers, and in Serbia almost two centuries later, at the time of establishing the Nemanjić dynasty. In Russia, the major events were the development of Novgorod and Moscow.

A higher level of town development was the construction of stone walls which appeared in Western Europe earlier than in Serbia as did settlements in the vicinity of fortresses and artillery. Medieval towns survived longer in Europe, some even take the same form today as they did in the Middle Ages, while most towns in Serbia were devastated during the reign of the Ottoman Empire. Medieval towns in Europe lost their function at the beginning of the New Era and today they mainly serve for the purpose of tourism.

\section{Acknowledgment}

This paper is part of the project No. II4-45I-I86I/2OII02 financed by the Provincial Secretariat for Science and Technological Development of the Vojvodina Province, Serbia.

\section{References}

Aurell, M., Power, D. 2006. ed., "Society", The Central Middle Ages: Europe 950-I320. The Short Oxford History of Europe, Oxford: Oxford University Press

Baker, A., R., H. 2004. On the history and geography of the International Conference of Historical Geographers. Journal of Historical Geography 36, I02-I04.

Baker, A.R.H. 2007. Conference report Thirteenth International Conference of Historical Geographers. Journal of Historical Geography 33, 429-430.

Barley, M.W. I975. The plans and topography of medieval towns in England and Wales. Ed. London: The Council for British Archaeology, Research report series, $92 \mathrm{pp}$.

Barnaba, E. I993. Le sang des marais. Marseille.

Beckett, J. 2005. City status in the United Kingdom. I830-2002.

Bošković, Đ. I972. Archeological researching of Novo Brdo. Kolarcev narodni univerzitet, Belgrade.

Bury, J., B. I958. History of the Later Roman Empire: From the Death of Theodosius I to the Death of Justinian. Dover Publications.

Buse, D. 2005. The Regions of Germany: a reference guide to history and culture. Greenwood Press.
Cathcart, K. David, J. I988. The Castle in England and Wales: an Interpretative History. London: Croom Helm.

Chandler, T. I987. Four thousand years of urban growth: An historical census, Lewiston, NY: Edwin Mellen Press.

Chartrand, R. Spedaliere, D. 2006. The Spanish Main I492-I800. Osprey Publishing.

Cathcart, K. David, J. I988. The Castle in England and Wales: an Interpretative History. London: Croom Helm.

Clark, H., Ambrosiani, B. I995. Towns in the Wiking Age (I99I; rev.edn I995).

Clarke, M., V. I926. The Medieval City State: An Essay on Tyranny and Federation in the Later Middle Ages. London.

Clive, R. I936. Old Towns of England. London.

Beresford, M., R., Finberg, H., P., R. I98I. English Medieval Boroughs: A handlist, (1973); extended in Urban History Yearbook, pp. 59-65.

Coulson, S. 2003. Castles in Medieval Society: Fortresses in England, France, and Ireland in the Central Middle Ages. Oxford: Oxford University Press.

Creighton, O. Higham, R. 2003. Medieval Castles. Shire Archaeology.

Creighton, O. 2002.Castles and Landscapes. London: Continuum.

Curčić, S. 1992. Geography of settlements. Faculty of Science, Novi Sad.

Cvijić, J. I922. Balkan peninsula and southslavica countries. Belgrade.

Deroko, A. I950. Medieval towns in Serbia, Montenegro and FYR of Macedonia. Prosveta, Belgrade.

Dickinson, R., E. 1945. The Morphology of the Medieval German Town. Geographical Review Vol. XXXV.

Ercegović - Pavlović, S. I975. Ras - medieval Trgoviste. Arheološki pregled I7, Belgrade.

Erlande-Brandenburg, A. I995. The Cathedral Builders of the Middle Ages. Thames \& Hudson Ltd.

Gebelin, F. 1964. The châteaux of France. H. Eaton Hart (English ed.), Presses Universitaires de France.

Gies J., Gies, F. I974. Life in a Medieval Castle. New York: Harper \& Row.

Girouard, M. I985. Cities and people: A social and architectural history.

Glennie, P., D. I992. Crisis and restructuring in late - medieval England and Wales. Journal of Historical geography $16,3,330-338$.

Harris, J. 2007. Constantinople: Capital of Byzantium. Hambledon Continuum.

Herlihy, D. I970. The History of Feudalism. London: Humanities Press.

Herrin, J. 2008. Byzantium: The Surprising Life of a Medieval Empire. Princeton University Press. 
Johnson, M. 2002. Behind the Castle Gate: From Medieval to Renaissance. London: Routledge.

Jones, R. 2002.Changing ideologies of medieval state formation: the growing exploitation of land in Gwyneed c. IIOO-I40O. Journal of Historical geography 26, 4, 505-516.

Kenyon, J. I99I. Medieval Fortifications. Leicester: Leicester University Press.

Kovačević, J. I977. Results of researching medieval Ras. Zbornik istorijskog muzeja Srbije I3-I4, Belgrade.

Koter, M., Kulesza, M. I999. The plans of medieval Polish Towns. Urban Morphology 3, 2, 63-78.

Kunt, I., M. 2003. Sultan, dynasty and state in the Ottoman Empire: Political Institutions in the $\mathrm{I}^{\mathrm{th}}$ century. The Medieval history Journal 6, 207.

Laszlovszky, J., Miklós, Z., Romhányi, B., Szende, K. 2003. The Archaeology of Hungary's Medieval Towns in Hungarian archaeology at the turn of the millennium. Ministry of National Cultural Heritage, Budapest, 364-372

Lilley, K., D. 2002. Urban life in the middle ages, I000-I450.

Lynch, M., Sperman, M., Stell, G. I988. The Scottish medieval town, Edinburgh: John Donald, 329.

Macura, M. 20oI. Settlements and population of Brankovic region in I455. SANU, Odeljenje drustvenih nauka, Belgrade.

Mesqui, J. I997. Chateaux-forts et fortifications en France. Paris: Flammarion.

Meurer, F., R. I9I4. Der mittelalterliche Stadtgrundriss im nördlichen Deutschland. Berlin.

Mišić, S. 20Io. Towns and market places in serbian medieval times, in Lexicon of towns and market places of serbian countries. Zavod za udzbenike, Belgrade.

Monreal Y Tejada, L. I999. Medieval Castles of Spain (English ed.), Konemann.

Morfill, W., R. I9I3. History of Russia, in W.R.Morfill and C.E.Frye, Russia and Poland. New York P.F.Collier \& Son, pp. 3-I5.

Morris, M. 2004. Castle: A History of the Buildings that Shaped Medieval Britain. London: Channel Four Books.

Mumford, L. 20or. The City in History, Its Origins, Its Transformations, and Its Prospects (Serbian ed.), Book Marso, Belgrade.

Novaković, S. I892. Town, borough, market place. Nastavnik, Belgrade.
Novaković, S. I9II. Nemanja's capitals, Istorijski glasnik 88, Belgrade

Palliser, D., M. 2006. Towns and local commumites in medieval and early modern England. Ashgate Variorum, Aldershot, 280 pp.

Petronijević, S. 2006. Smederevo, capital city of Serbia. Smederevo.

Pirenne, H. I948. Medieval Cities. Translated from the French by Frank D. Halsey, Princeton.

Platt, C. I976. The English medieval town. London: Sector and Warburg, 219 pp.

Reynolds, S. I977. An introdution to the history of English medieval towns. Oxford: Clarendon Press, $234 \mathrm{pp}$.

Pounds, N.J.G. I994. The Medieval Castle in England and Wales: A Social and Political History. Cambridge: Cambridge University Press.

Rašević, M. I996. Conceptual and methodological issues of demographic estimates. SANU, Belgrade.

Ribhegge, 2003. W. City and Nation in Germany from the Middle Ages to the Present: The Origins of the Modern Civil Society in the Urban Tradition. Journal of Urban History 30, 2 I.

South, R. I977. The book of Winsor. Barracuda books, $35 \mathrm{pp}$.

Tarabandina, O.A. 2009. Dendrochronological studies of medieval Novgorod (Based on the findings of archaeological excavations I99I2006). Archaelogy, Etnology \& Antropology of Eurasia 37, I, 77-84

Stojsavljević, R., Vujičić, M., Đerčan, B., ĐurĐev, B. 2oro. Serbian medieval towns and their tourist potentials. Geographica timisiensis I9, I, I89I96.

Taylor, A. I986. The welsch castles of Edward I. London, Hambledon Press.

Tout, F., T. I934. Medieval Town Planning in England. Manchester.

Treadgold, W. I997. A History of the Byzantine State and Society. Stanford University Press.

Vigneswaran, D. 2007. The Territorial Strategy of the Italian City-State. International Relations 2I, 427.

Vresk, M. 2002. Development of world urban systems. Skolska knjiga, Zagreb.

Wacher, J. I995. The towns of Roman Britain. $2^{\text {nd }}$ edition.

Zdravković, I. I958. Excavation on Novo Brdo site in I955. Starinar VII - VIII, Belgrade.

http://www.medieval-castles.net/castles.htm 